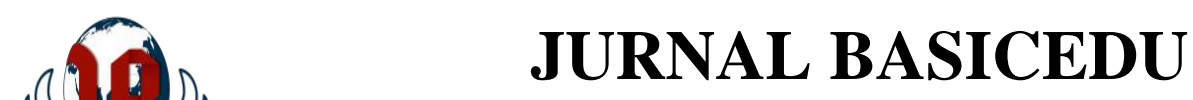

Volume 5 Nomor 5 Tahun 2021 Halaman 3260 - 3269

Research \& Learning in Elementary Education

https://jbasic.org/index.php/basicedu

PAHLAWAN

\title{
Pengaruh Penggunaan Media Video Pembelajaran terhadap Hasil Belajar pada Mata Pelajaran Matematika Siswa Sekolah Dasar
}

\author{
Yunita Prastica ${ }^{\circledR}$, Muhammad Thamrin Hidayat ${ }^{2}$, Syamsul Ghufron ${ }^{3}$, Akhwani $^{4}$ \\ Universitas Nahdlatul Ulama Surabaya, Indonesia ${ }^{1,2,3,4}$ \\ E-mail: yunitaprastica34@gmail.com¹ㄴ.thamrin@unusa.ac.id ${ }^{2}$, syamsulghufron@unusa.ac.id ${ }^{3}$, \\ akhwani@unusa.ac.id ${ }^{4}$
}

\begin{abstract}
Abstrak
Penelitian ini dilakukan berkaitan dengan adanya permasalahan terkait hasil belajar siswa pada mata pelajaran matematika masih rendah, karena sebagian siswa kesulitan dalam pembelajaran matematika. Tujuan dari penelitian ini yaitu untuk mengetahui hasil belajar matematika siswa sebelum dan sesudah digunakan media video pembelajaran pada siswa kelas IV di SDN Kedungbanteng Sidoarjo dan mengetahui adanya pengaruh terhadap hasil belajar matematika siswa digunakan media video pembelajaran pada siswa kelas IV di SDN Kedungbanteng Sidoarjo. Metode penelitian yang digunakan kuantitatif deskriptif. Hasil belajar matematika siswa sebelum digunakan media video pembelajaran pada siswa kelas IV di SDN Kedungbanteng Sidoarjo dengan nilai rata-rata 43,29 pada kualifikasi rendah, hasil belajar matematika siswa sesudah digunakan media video pembelajaran pada siswa kelas IV di SDN Kedungbanteng Sidoarjo dengan nilai rata-rata 87,94 pada kualifikasi tinggi serta terdapat pengaruh yang signifikan terhadap hasil belajar matematika siswa digunakan media video pembelajaran pada siswa kelas IV di SDN Kedungbanteng Sidoarjo dengan $t_{\text {hitung }} 9,461>t_{\text {tabel }}$ 1,696. Dengan kata lain, media video pembelajaran berpengaruh digunakan dalam mata pelajaran matematika. Kata Kunci: Media video pembelajaran, Matematika, Hasil belajar.
\end{abstract}

\begin{abstract}
This research was conducted related to the existence of problems related to student learning outcomes in mathematics subjects are still low, because some students have difficulty in learning mathematics. The purpose of this study was to determine students' mathematics learning outcomes before and after using instructional video media for fourth grade students at SDN Kedungbanteng Sidoarjo and to find out the influence on students' mathematics learning outcomes using instructional video media for fourth grade students at SDN Kedungbanteng Sidoarjo. The research method used is descriptive quantitative. Students' mathematics learning outcomes before using instructional video media for fourth grade students at SDN Kedungbanteng Sidoarjo with an average value of 43.29 for low qualifications, students' mathematics learning outcomes after using instructional video media for fourth grade students at SDN Kedungbanteng Sidoarjo with an average value an average of 87.94 in high qualification and there is a significant effect on students' mathematics learning outcomes using instructional video media for fourth grade students at SDN Kedungbanteng Sidoarjo with tcount 9,461 > ttable 1,696. In other words, influential learning video media are used in mathematics subjects.
\end{abstract}

Keywords: Learning video media, Mathematics, learning outcomes.

Copyright (c) 2021 Yunita Prastica, Muhammad Thamrin Hidayat, Syamsul Ghufron, Akhwani

Corresponding author :

Email : yunitaprastica34@gmail.com

DOI : https://doi.org/10.31004/basicedu.v5i5.1327

ISSN 2580-3735 (Media Cetak)

ISSN 2580-1147 (Media Online)

Jurnal Basicedu Vol 5 No 5 Tahun 2021

p-ISSN 2580-3735 e-ISSN 2580-1147 
3261 Pengaruh Penggunaan Media Video Pembelajaran terhadap Hasil Belajar pada Mata Pelajaran Matematika Siswa Sekolah Dasar - Yunita Prastica, Muhammad Thamrin Hidayat, Syamsul Ghufron, Akhwani

DOI: https://doi.org/10.31004/basicedu.v5i5.1327

\section{PENDAHULUAN}

Pendidikan merupakan hal yang paling penting dalam mewujudkan manusia yang berilmu, berbudaya, bertakwa untuk menjamin keberlangsungan pembangunan suatu bangsa. Karena pendidikan adalah usaha sadar yang dibuat oleh pemerintah melalui kegiatan pengajaran atau latihan, yang dilangsungkan di sekolah maupun diluar sekolah guna mempersiapkan siswa agar bisa berperan dalam berbagi lingkungan hidup secara tepat dimasa akan datang. Guru disekolah merupakan salah satu faktor eksternal yang sangat berperan dalam mempengaruhi hasil belajar peserta didik (Zunidar, 2019). Maka dari itu, guru diharuskan untuk membuat perencanaan secara cermat dalam meningkatkan hasil belajar dan memperbaiki kualitas pada pengajarannya. Dalam hal tersebut menuntut agar adanya perubahan-perubahan dalam penggunaan strategi pembelajaran, ataupun karakteristik guru dalam mengelola proses pembelajaran. Pencapaian tujuan pendidikan dikatakan berhasil tidaknya bergantung pada bagaimana proses belajar mengajar dilakukan dan yang dijalani oleh siswa (Sarosa \& Khairudin, 2016).

Media pembelajaran adalah seperangkat alat yang membantu seorang pendidik dalam menyampaikan pengajarannya kepada siswa secara menarik. Penggunaan media pembelajaran online berbasis audio-visual juga sangat membantu aktivitas proses pembelajaran peserta didik baik di dalam kelas maupun di luar kelas, terutama membantu meningkatkan hasil belajar siswa (Indrawati, 2012). Hasil belajar merupakan suatu hasil yang didapat dari hasil belajar. Hasil belajar itu dicapai dalam nilai yang melihat suatu hasil, yang terjadi yaitu adanya perubahan kognitif, afektif, maupun psikomotorik. Hasil belajar merupakan kemahiran yang diperoleh siswa sesudah mendapatkan pengalaman belajar (Sudjana, 2009). Hal tersebut akan membuat pembelajaran berlangsung secara kondusif, menarik, nyaman, dan menyenangkan dan berjalan dengan efektif dan efisien apabila guru dituntut dapat memanfaatkan dan menggunakan media yang lebih ekonomis, dan efesien serta berusaha melakukan inovasi dalam pembelajaran (Usman, 2002).

Pembelajaran daring sedang dilaksanakan di seluruh Indonesia karena adanya virus COVID-19 yang mengharuskan sekolah melakukan proses pembelajaran jarak jauh. Adanya faktor lain yang menyebabkan terhambatnya pembelajaran daring yaitu rendahnya variasi dan media pembelajaran yang dilaksanakan guru dalam proses pembelajaran (Arafah, 2018). Selama pembelajaran jarak jauh ini, kebanyakan guru hanya memberikan tugas kepada siswa melalui grup whatsApp berupa foto halaman atau ketikan yang akan dibuat tugas. Kemajuan ilmu pengetahuan, teknologi informasi dan komunikasi yang demikian cepat diharapkan membawa dampak positif bagi kemajuan dunia pendidikan di masa sekarang ini (Nurdiansah, 2017). Era digitalisasi yang sekarang lebih dikenal dengan era revolusi industri 4.0, telah merambah ke berbagai sektor termasuk pendidikan. Hal ini dapat menjadi media yang sangat efektif dan efisien untuk digunakan sebagai penunjang proses pembelajaran. Berbagai fasilitas multi media berbasis IT dapat dimanfaatkan agar proses pembelajaran menjadi lebih menarik. Dengan meningkatnya perkembangan ilmu pengetahuan dan teknologi. Pendidik dapat menerapkan media pembelajaran berbasis online dalam proses pembelajaran di dalam kelas maupun di luar kelas secara lebih menarik dan inovatif salah satunya media yang berbasis audio visual yaitu media video pembelajaran (Sawitri, 2019).

Matematika merupakan salah satu mata pelajaran yang termasuk harus ada dalam pembelajaran sekolah dasar dan sampai ke jenjang berikutnya. Hal ini agar siswa dapat berpikir secara logis, analitis, sistematis, dan kritis. Salah satu permasalahan terdapat rendahnya hasil belajar siswa yang paling banyak mengalami kesulitan dalam setiap peningkatannya adalah matematika, dan materi yang dianggap sulit oleh siswa kelas IV di SDN KedungBanteng yaitu menghitung dan memasukkan cara keliling dan luas persegi panjang (Suciyati \& Mariamah, 2018). Dan cara untuk membangunkan semangat belajar dan tanggung jawab siswa dalam proses pembelajaran yaitu dengan mengubah model/media pembelajaran yang selama ini tidak diminati lagi oleh siswa, seperti proses pembelajaran yang dilakukan dengan ceramah atau tanya jawab yang akhirnya 
3262 Pengaruh Penggunaan Media Video Pembelajaran terhadap Hasil Belajar pada Mata Pelajaran Matematika Siswa Sekolah Dasar - Yunita Prastica, Muhammad Thamrin Hidayat, Syamsul Ghufron, Akhwani

DOI: https://doi.org/10.31004/basicedu.v5i5.1327

membuat siswa merasa jenuh dan kurang efektif. Kebanyakan siswa menganggap pelajaran matematika merupakan mata pelajaran yang paling sulit dan rumit. Dan sampai saat ini masih banyak siswa yang merasa takut untuk belajar matematika. Hal tersebut dikarenakan pembelajaran dilakukan secara monoton (Badriyah, 2017). Dan kegiatan tersebut masih berlangsung di sebagian lembaga pendidikan, tak terkecuali pada siswa kelas IV di SDN Kedungbanteng Sidoarjo. Akibat dari hal tersebut berpengaruh pada hasil belajar yang terjadi pada siswa kelas IV di SDN Kedungbanteng Sidoarjo yang hasil belajar matematikanya rendah. Oleh sebab itu, perlu dilakukannya perubahan dalam proses pembelajaran agar menyenangkan (Gunawan, 2020).

Media video pembelajaran merupakan media pembelajaran berbasis audio visual ini berisi penjabaran materi yang disuguhkan dengan gambar atau animasi-animasi menarik yang bersamaan dengan suara yang digunakan untuk menjelaskan materi secara jelas dan padat (Fauziyyah, 2019). Media dalam proses belajar mengajar cenderung diartikan sebagai alat-alat grafis, photografis, atau elektronis untuk menangkap, memproses, dan menyusun kembali informasi visual atau verbal. Karena media video pembelajaran juga dapat siswa lihat berkali-kali apabila lupa akan materi belajarnya. Dengan media video pembelajaran ini guru dapat mengetahui pemahaman peserta didik mengenai pembelajaran yang telah disampaikan meningkat atau tidak. Media video pembelajaran bisa digunakan oleh guru untuk melihat sejauh mana siswa dalam belajar (Murningsih, 2014).

Berdasarkan pemikiran tersebut, peneliti sangat tertarik melakukan penelitian tentang penggunaan media video pembelajaran terhadap hasil belajar siswa pada mata pelajaran matematika. Oleh karena itu, peneliti memilih judul "Pengaruh Penggunaan Media Video Pembelajaran Terhadap Hasil Belajar pada Mata Pelajaran Matematika Siswa Sekolah Dasar".

Penelitian ini juga memiliki tujuan sebagai berikut: 1) Untuk mengetahui hasil belajar matematika siswa sebelum digunakan media video pembelajaran pada siswa kelas IV di SDN Kedungbanteng Sidoarjo. 2) Untuk mengetahui hasil belajar matematika siswa sesudah digunakan media video pembelajaran pada siswa kelas IV di SDN Kedungbanteng Sidoarjo. 3) Untuk mengetahui adanya pengaruh terhadap hasil belajar matematika siswa dalam penggunaan media video pembelajaran pada siswa kelas IV di SDN Kedungbanteng Sidoarjo.

Penelitian tentang penggunaan video pembelajaran juga dilakukan oleh Resky Azis (2018) dengan judul penelitian "Pengaruh Penggunaan Video Pembelajaran Terhadap Motivasi dan Hasil Belajar Siswa Pada Materi Sistem Peredaran Darah". Hasil Penelitiannya menunjukkan bahwa terdapat pengaruh yang positif serta signifikan diantara motivasi dan hasil belajar siswa. Hal tersebut dapat dilihat pada kategori nilai ratarata sebesar 78,71 dan 70,93. Motivasi dan hasil belajar siswa yang dibelajarkan dengan Media Video berada pada kategori tinggi dengan nilai rata-rata sebesar 83,79 dan 77,17 . Ada pengaruh penggunaan media video terhadap motivasi dan hasil belajar siswa dengan nilai signifikansi 0.002 dan 0,016 (Azis et al., 2018).

Berdasarkan penelitian Lina Novita (2019) juga melakukan penelitian dengan judul "Penggunaan Media Pembelajaran Video terhadap Hasil Belajar Siswa SD”. Hasil penelitian Lina Novita menunjukkan bahwa terdapat pengaruh yang positif dan signifikan antara penggunaan media pembelajaran audio visual video terhadap hasil belajar Subtema 1 Keberagaman Budaya Bangsaku pada kelas IV A dan IV B Sekolah Dasar Negeri Babakan 01 Semester 1 Tahun Ajaran 2019/2020. Hal ini dapat dilihat dari nilai NGain pada kelompok kelas eksperimen sebesar 76, sedangkan pada kelompok kelas kontrol mendapatkan nilai N-Gain sebesar 68. Ketuntasan hasil belajar yang diperoleh kelompok kelas eksperimen adalah 85\%, sedangkan pada kelompok kelas kontrol ketuntasan hasil belajar sebesar $75 \%$, kemudian hasil pengujian hipotesis menyatakan bahwa Ho ditolak dan Ha diterima karena thitung $(2,5414)>(1,9983)$ (Novita et al., 2019). 
3263 Pengaruh Penggunaan Media Video Pembelajaran terhadap Hasil Belajar pada Mata Pelajaran Matematika Siswa Sekolah Dasar - Yunita Prastica, Muhammad Thamrin Hidayat, Syamsul Ghufron, Akhwani

DOI: https://doi.org/10.31004/basicedu.v5i5.1327

\section{METODE PENELITIAN}

Penelitian ini menggunakan metode pendekatan kuantitatif. Menurut Trijono (2015) yang dimaksud Penelitian kuantitatif adalah salah satu jenis penelitian yang spesifikasinya adalah sistematis, terencana, dan terstruktur dengan jelas mulai awal hingga pembuatan desain penelitiannya (Amrah et al., 2020). Dengan metode yang digunakan dalam penelitian ini yaitu eksperimen. Desain eksperimen yang digunakan dalam penelitian ini adalah True Eksperiment Design, yaitu jenis-jenis eksperimen yang dianggap baik karena sudah memenuhi persyaratan. Metode penelitian ini menggunakan jenis desain Pre-Eksperimental Model OneGroup Pretest Posttest. Di mana hasil perlakuan dapat diketahui lebih akurat karena membandingkan sebelum dan sesudah diberi perlakuan (Amalia, 2015). Populasi penelitian ini adalah siswa kelas IV yang berjumlah 31 dengan perincian 15 laki-laki dan 16 perempuan di SDN Kedungbanteng Sidoarjo. Penelitian ini menggunakan seluruh anggota populasi dan disebut sampel jenuh, jumlah populasi $<100$ orang sehingga mengambil seluruh populasi yang ada yaitu sejumlah 31 siswa. Adapun teknik pengumpulan data yang digunakan dalam penelitian ini dengan tes diberikan kepada peserta didik yaitu sebelum proses pembelajaran dimulai (pretest) dan setelah proses pembelajaran dimulai (posttest).

Untuk menguji instrumen penelitian dilakukan uji validasi ahli, uji validasi SPSS dan uji reliabilitas. Validasi ahli dilakukan untuk menguji perangkat pembelajaran RPP dan tes soal mata pelajaran matematika (pretest dan posttest). Uji validasi penelitian ini meliputi validasi perangkat pembelajaran RPP dan soal pretest dan postest yang dilakukan oleh dua ahli dilakukan dengan cara menghitung data dengan menggunakan SPSS for windows versi 25. Uji reliabilitas dalam penelitian ini derajat konsistensi dari suatu instrumen suatu tes dengan melakukan perhitungan Alpha, digunakan alat bantu berupa perangkat lunak computer yaitu SPSS versi 25 windows dengan model Alpha. Selain itu dilakukan juga Uji coba kesukaran soal dilakukan untuk mengetahui seberapa tinggi tingkat kesukaran pada setiap butir soal. Dilakukan dengan cara menghitung data dengan menggunakan SPSS for windows versi 25 (Azis et al., 2018). Dalam penelitian ini menggunakan pengumpulan data kuantitatif dan teknik analisis data yang digunakan yaitu: Uji Normalitas menggunakan uji kolmogorov smirnov yang terdapat dalam SPSS versi 25 karena subjek penelitian kecil berjumlah 31 siswa. Uji homogenitas dilakukan dengan One Way Anova yang terdapat dalam program SPSS versi 25. Setelah uji normalitas dan uji homogenitas selesai dilakukan, dapat dilanjut dengan tahap selanjutnya yaitu uji hipotesis. Jika data berdistribusi normal dan homogeny, dapat di lanjutkan uji statistic parametric dengan uji paired sample $t$ test dalam program SPSS versi 25 untuk mencari ada tidaknya perbedaan penerapan media video pembelajaranterhadap hasil belajar siswa melalui nilai pretest dan posttest. Akan tetapi jika data tidak normal dan tidak homogeni, uji hipotesisnya dapat menggunakan statistic non parametik dengan analisis uji Wilcoxon matched pairs dalam program SPPSS versi 25 (Arcat, 2020).

\section{HASIL DAN PEMBAHASAN}

Hasil belajar matematika siswa kelas IV SDN Kedungbanteng Sidoarjo sebelum digunakan video pembelajaran berdasarkan data hasil pretest yang terdiri dari 9 soal terhadap 31 responden siswa dapat dikelompokkan menjadi 3 kategori hasil belajar

Tabel 1. Hasil Belajar Siswa Kelas IV SDN Kedungbanteng Sidoarjo

\begin{tabular}{cccc}
\hline Skala interval & Frekuensi & Presentase & Kategori \\
\hline $\mathrm{X} \geq 80$ & 4 & $13,0 \%$ & Tinggi \\
\hline $60 \leq \mathrm{X}<80$ & 2 & $6,4 \%$ & Sedang \\
\hline $\mathrm{X}<60$ & 25 & $80,6 \%$ & Rendah \\
\hline
\end{tabular}


3264 Pengaruh Penggunaan Media Video Pembelajaran terhadap Hasil Belajar pada Mata Pelajaran Matematika Siswa Sekolah Dasar - Yunita Prastica, Muhammad Thamrin Hidayat, Syamsul Ghufron, Akhwani

DOI: https://doi.org/10.31004/basicedu.v5i5.1327

31

$100 \%$

Sumber: Data primer penelitian

Tabel 2. Hasil Belajar Siswa Kelas IV SDN Kedungbanteng Sidoarjo

\begin{tabular}{cccc}
\hline Skala interval & Frekuensi & Presentase & Kategori \\
\hline $\mathrm{X} \geq 80$ & 23 & $74,0 \%$ & Tinggi \\
\hline $60 \leq \mathrm{X}<80$ & 8 & $26,0 \%$ & Sedang \\
\hline $\mathrm{X}<60$ & 0 & $0 \%$ & Rendah \\
\hline
\end{tabular}

Sumber: Data primer penelitian

Berdasarkan kedua tabel diatas dapat dilihat bahwa hasil belajar matematika siswa sebelum menggunakan media video pembelajaran dengan kemampuan tinggi dengan presentase sebesar 13,0\% (4 siswa), kemampuan sedang dengan presentase sebesar 6,4\% (2 siswa), dan 80,6\% (25 siswa) berkemampuan rendah. Sedangkan hasil belajar matematika siswa sesudah menggunakan media video pembelajaran dengan kemampuan tinggi dengan presentase sebesar 74,0\% (23 siswa), kemampuan sedang dengan presentase sebesar 26,0\% (8 siswa), dan 0\% (0 siswa) berkemampuan rendah. Hal ini menunjukkan bahwa hasil belajar siswa kelas IV SDN Kedungbanteng Sidoarjo pada mata pelajaran matematika sesudah menggunakan media video pembelajaran berada pada kategori tinggi.

Data yang sudah dikumpulkan oleh penulis selanjutnya dilakukan uji normalitas dan uji homogenitas menggunakan bantuan SPSS.

Tabel 3. Uji Normalitas

\begin{tabular}{|c|c|c|}
\hline \multicolumn{3}{|c|}{ One-Sample Kolmogorov-Smirnov Test } \\
\hline \multicolumn{3}{|c|}{ Unstandardized Residual } \\
\hline $\mathrm{N}$ & & 31 \\
\hline \multirow[t]{2}{*}{ Normal Parameters ${ }^{\mathrm{a}, \mathrm{b}}$} & Mean & .0000000 \\
\hline & Std. Deviation & 6.81960457 \\
\hline \multirow{3}{*}{ Most Extreme Differences } & Absolute & .149 \\
\hline & Positive & .136 \\
\hline & Negative & -.149 \\
\hline Test Statistic & & .149 \\
\hline Asymp. Sig. (2-tailed) & & $.079^{\circ}$ \\
\hline \multicolumn{3}{|l|}{ a. Test distribution is Normal. } \\
\hline b. Calculated from data. & & \\
\hline c. Lilliefors Significance Correction. & & \\
\hline
\end{tabular}

Tabel 3 diatas menunjukkan nilai signifikansi data penelitian ini adalah 0,079 yang dimana apabila nilai signifikansi $\geq 0,05$, maka data berdistribusi normal. Hal ini berarti bahwa data penelitian ini dinyatakan berdistribusi normal.

Tabel 4. Uji Homogenitas

\begin{tabular}{llrrrr}
\hline & \multicolumn{2}{c}{ Test of Homogeneity of Variances } & & & \\
\hline & Levene Statistic & Df1 & \multicolumn{1}{c}{ Df2 } & \multicolumn{1}{c}{ Sig. } \\
\hline \multirow{3}{*}{ Hasil Belajar } & Based On Mean & .214 & 6 & 24 & .969 \\
\cline { 2 - 6 } & Based On Median & .271 & 6 & 24 & .945 \\
\cline { 2 - 6 } & Based On Median And With Adjusted Df & .271 & 6 & 19.865 & .944 \\
\hline
\end{tabular}


3265 Pengaruh Penggunaan Media Video Pembelajaran terhadap Hasil Belajar pada Mata Pelajaran Matematika Siswa Sekolah Dasar - Yunita Prastica, Muhammad Thamrin Hidayat, Syamsul Ghufron, Akhwani

DOI: https://doi.org/10.31004/basicedu.v5i5.1327

Sumber: Data primer penelitia

Based On Trimmed Mean

$.233 \quad 6$

$24 \quad .962$

Berdasarkan Tabel 4 uji homogenitas dengan menggunakan metode levens statistics seperti table diatas, didapatkan nilai signifikan sebesar 0,969>0,05, dengan demikian dapat dikatakan data penelitian tersebut adalah homogen.

Selain itu, dilakukan uji validasi ahli, uji validasi dan uji reabilitas. Setelah dilakukan uji validasi ahli oleh validator 1 dan validator 2 didapatkan nilai rata-rata dari validator 1 sebesar 3,75 dengan catatan ada sedikit revisi. Sedangkan untuk nilai rata-rata dari validator 2 sebesar 3,89 dengan catatan tanpa revisi. Instrument ini telah di revisi sesuai saran dari validator, sehingga layak digunakan. Dari kedua nilai rata-rata yang diperoleh nilai rata-rata secara keseluruhan yaitu 3,82 sehingga kesimpulan dari perangkat pembelajaran RPP layak digunakan dengan sedikit revisi. Berdasarkan hasil perhitungan diketahui bahwa kedua data penilaian validator ahli untuk hasil penilaian RPP adalah valid karena besar $r$ hitung $\geq r$ tabel $(0,3550)$.

Hasil perhitungan menggunakan SPSS menunjukkan bahwa instrumen tes untuk hasil belajar siswa pada mata pelajaran matematika materi keliling dan luas persegi panjang berjumlah 10 pertanyaan terdapat 9 butir pernyataan yang dinyatakan valid dan 1 butir soal yang dinyatakan tidak valid dibuktikan dengan hasil perhitungan menggunakan program SPSS Versi 25 yang dilakukan peneliti dengan membandingkan $\mathrm{r}$ hitung dengan $r$ tabel. Jika $r$ hitung $\geq r$ tabel $(0,355)$ maka soal dinyatakan valid, sedangkan jika $r$ hitung $\leq r$ tabel $(0,355)$ maka soal dinyatakan tidak valid. Pada uji reabilitas menunjukkan bahwa instrumen penelitian ini memiliki kriteria reliabel karena menghasilkan nilai Alpha Cronbach sebesar 0,709 untuk butir soal subjektif. Kesimpulan dari hasil uji reliabilitas dapat dikatakan reliabel karena memiliki nilai Alpha Cronbach $\geq 0,60$.

Setelah memperhatikan karakteristik variabel yang telah diteliti dan persyaratan analisis, selanjutnya dilakukan pengujian terhadap hipotesis. Untuk pengujian hipotesis, langkah yang dilakukan adalah menganalisis hasil uji-t adapun hasil uji t dapat dilihat pada tabel dibawah ini:

Tabel 5. Paired Samples Statistics

\begin{tabular}{|c|c|c|c|c|c|}
\hline \multicolumn{6}{|c|}{ Paired Samples Statistics } \\
\hline & & Mean & $\mathrm{N}$ & Std. Deviation & Std. Error Mean \\
\hline \multirow[t]{2}{*}{ Pair 1} & Pretest & 43.29 & 31 & 27.554 & 4.949 \\
\hline & Postest & 87.94 & 31 & 7.160 & 1.286 \\
\hline
\end{tabular}

Sumber: Data primer penelitian

Berdasarkan Tabel 5 menunjukkan bahwa terdapat perbedaan nilai rata-rata (mean) dari nilai pre-test adalah 43,29 sedangkan post-test adalah 87,94. Untuk membuktikan adanya perbedaan dari nilai pre-test dan post-test.

Tabel 6. Paired Samples Test 

Matematika Siswa Sekolah Dasar - Yunita Prastica, Muhammad Thamrin Hidayat, Syamsul Ghufron, Akhwani

DOI: https://doi.org/10.31004/basicedu.v5i5.1327

\section{Paired Samples Test}

\begin{tabular}{|c|c|c|c|c|c|c|c|c|}
\hline & \multicolumn{5}{|c|}{ Paired Differences } & \multirow[b]{3}{*}{$\mathrm{t}$} & \multirow[b]{3}{*}{$\mathrm{df}$} & \multirow{3}{*}{$\begin{array}{l}\text { Sig. (2- } \\
\text { tailed) }\end{array}$} \\
\hline & \multirow[b]{2}{*}{ Mean } & \multirow{2}{*}{$\begin{array}{c}\text { Std. } \\
\text { Deviation }\end{array}$} & \multirow{2}{*}{$\begin{array}{l}\text { Std. Error } \\
\text { Mean }\end{array}$} & \multicolumn{2}{|c|}{$\begin{array}{l}95 \% \text { Confidence } \\
\text { Interval of the } \\
\text { Difference }\end{array}$} & & & \\
\hline & & & & Lower & Upper & & & \\
\hline $\begin{array}{l}\text { Hasil } \\
\text { Belajar }\end{array}$ & -44.645 & 26.274 & 4.719 & -54.282 & -35.008 & -9.461 & 30 & .000 \\
\hline
\end{tabular}

Dari tabel di atas, hasil analisis data diketahui bahwa nilai signifikan sebesar 0,000 lebih kecil dari signifikansi $0,05(0,000<0,05)$, maka hipotesis $\left(H_{1}\right)$ dalam penelitian ini dinyatakan diterima. Artinya, terdapat pengaruh yang signifikan antara hasil belajar siswa sebelum menggunakan media video pembelajaran dengan sesudah menggunakan media video pembelajaran pada siswa kelas IV di SDN Kedungbanteng Sidoarjo.

\section{Hasil Belajar Matematika Siswa Sebelum digunakan Media Video Pembelajaran pada Siswa Kelas IV di SDN Kedungbanteng Sidoarjo Tergolong Rendah}

Hasil penelitian di atas menyimpulkan bahwa hasil belajar pada mata pelajaran matematika siswa sebelum menggunakan video pembelajaran atau pretest ini masih rendah. Hal tersebut dapat dilihat dari nilai rata-rata hasil belajar pada mata pelajaran matematika siswa kelas IV SDN Kedungbanteng Sidoarjo adalah 43,29 . Sesuai dengan skala penilaian, hasil belajar siswa yang termasuk dalam kategori rendah $(<60)$.

Proses pembelajaran sebelum menggunakan media video pembelajaran siswa terlihat kurang mampu menguasai mata pelajaran matematika dengan baik, karena pembelajaran matematika yang biasa dilakukan selama kegiatan daring hanya memberikan foto materi pelajaran dan pertanyaan yang harus dijawab oleh siswa melalui whatsapp group tanpa adanya penjelasan dari guru. Terkadang juga, mengirimkan sebuah video yang di mana berisi rekaman tangan yang sedang menulis untuk menerangkan secara tidak variatif, sehingga siswa tidak ingin melihat atau memutar video tersebut. Sehingga ketika diadakan tes pada mata pelajaran matematika materi keliling dan luas persegi panjang terlihat dari hasil nilai rata-rata siswa masih banyak yang belum sepenuhnya memahami dan menguasai. Hal-hal yang harus diperhatikan saat proses pembelajaran. Adapun pada saat pembelajaran melalui whatssapp group berlangsung kebanyakan siswa tidak banyak yang merespon, kurang menguasai materi keliling dan luas persegi panjang. Hal tersebut disebabkan karena mereka merasa bosan dan kurang semangat. Selama ini metode yang digunakan pada saat pembelajaran matematika yaitu teacher centered yang dimana guru menerangkan dan siswa mencatat lalu mengerjakan tugas, tanpa adanya media pembelajaran.

\section{Hasil Belajar Matematika Siswa Sesudah digunakan Media Video Pembelajaran pada Siswa Kelas IV di SDN Kedungbanteng Sidoarjo Tergolong Rendah}

Hasil penelitian di atas menyimpulkan bahwa hasil belajar pada mata pelajaran matematika siswa sesudah menggunakan video pembelajaran atau posttest ini tergolong tinggi. Hal tersebut dapat dilihat dari nilai rata-rata hasil belajar pada mata pelajaran matematika siswa kelas IV SDN Kedungbanteng Sidoarjo adalah 87,94 . Sesuai dengan skala penilaian, hasil belajar siswa yang termasuk dalam kategori tinggi $(\geq 80)$.

Proses pembelajaran dengan menggunakan media video pembelajaran mula-mulanya diperkenalkan kepada siswa tentang video pembelajaran yang digunakan oleh peneliti dengan mengadopsi video pembelajaran dari youtube seseorang yang bernama Mutiara Eka Betari serta kegunaannya dengan langkah- 
3267 Pengaruh Penggunaan Media Video Pembelajaran terhadap Hasil Belajar pada Mata Pelajaran Matematika Siswa Sekolah Dasar - Yunita Prastica, Muhammad Thamrin Hidayat, Syamsul Ghufron, Akhwani

DOI: https://doi.org/10.31004/basicedu.v5i5.1327

langkah proses pembelajaran sebagai berikut (1) guru mengirimkan video pembelajaran yang variatif kepada siswa melalui whatsapp group tentang materi keliling dan luas persegi panjang (2) selanjutnya, siswa diminta untuk melihat video tersebut dengan fokus dari handphone masing-masing. (3) setelah siswa melihat video pembelajaran yang sudah di kirimkan oleh guru, siswa diminta untuk bertanya atau merespon mengenai video pembelajaran yang sudah dikirimkan oleh guru. (4) kemudian, guru dan siswa melakukan video call secara bergantian untuk melakukan evaluasi mengenai materi keliling dan luas persegi panjang pada mata pelajaran matematika.

Saat kegiatan pembelajaran melalui whatsapp group dan video call terlihat siswa sangat antusias dan bersemangat. Hal ini dibuktikan dari keaktifan siswa yang sangat tampak pada saat merespon video yang dikirimkan melalui whatsapp group dan bertanya serta menjawab pada saat evaluasi melalui video call. Siswa yang awalnya malas, jarang merespon, susah untuk bertanya dan menjawab, tidak bersemangat untuk melakukan kegiatan pembelajaran dengan adanya video pembelajaran yang variatif dan tidak membosankan ini siswa ketagihan untuk dikirimkan video pembelajaran yang variatif pada materi-materi berikutnya. Bahkan terdapat beberapa siswa yang ingin melihat berulang kali video pembelajarannya tanpa ada rasa bosan. Hal tersebut terbukti bahwa media video pembelajaran ini dapat mengubah perilaku siswa karena dapat memotivasi dan menciptakan rasa keberhasilan serta meningkatkan rasa semangat pada diri siswa. Selain itu, media video pembelajaran yang variatif ini merupakan suatu hal yang baru bagi mereka, karena selama proses pembelajaran daring tersebut belum pernah ada guru yang menggunakan media video pembelajaran yang variatif terdapat banyak animasi dan gambar di dalamnya, apalagi media ini berupa audio-visual.

Video pembelajaran adalah suatu paling efektif secara medium yang dipakai untuk menolong proses pembelajaran, baik dalam pembelajaran berkelompok maupun individu (Daryanto, 2016: 86). Dengan tanpa media video pembelajaran guru cenderung monoton dalam proses pembelajaran hanya menggunakan penjelasan yang bersifat ceramah. Padahal mata pelajaran matematika adalah salah satu mata pelajaran yang membutuhkan tingkat konsentrasi yang tinggi, akan tetapi siswa terlihat sangat kurang bersemangat serta minat mereka dalam pelajaran matematika masih rendah.

Dengan media video pembelajaran yang variatif ini kesulitan diatas dapat diatasi, media ini menciptakan suasana pembelajaran yang lebih aktif dan menyenangkan. Sehingga teknik pembelajaran ini dapat mendorong minat belajar siswa dan dapat meningkatkan hasil belajar siswa pada mata pelajaran matematika.

\section{Ada Pengaruh Penggunaan Media Video Pembelajaran terhadap Hasil Belajar pada Mata Pelajaran Matematika pada Siswa Kelas IV SDN Kedungbanteng Sidoarjo}

Hasil penelitian di atas menyimpulkan bahwa ada pengaruh penggunaan media video pembelajaran. Hal tersebut dapat dilihat dari hasil uji paired sample t-test nilai signifikan sebesar 0,000 lebih kecil dari signifikan $0,05(0,000<0,05)$, sehingga hipotesis $\left(H_{1}\right)$ diterima. Artinya, bahwa variabel penggunaan media video pembelajaran berpengaruh terhadap hasil belajar pada mata pelajaran matematika siswa, ada pengaruh yang signifikan antara hasil belajar pada mata pelajaran matematika sebelum menggunakan media video pembelajaran dengan sesudah menggunakan media video pembelajaran pada siswa di kelas IV SDN Kedungbanteng Sidoarjo.

Dibawah ini rekapan hasil belajar siswa berdasarkan nilai rata-rata pretest (sebelum menggunakan video pembelajaran) dan posttest (sesudah menggunakan video pembelajaran). 


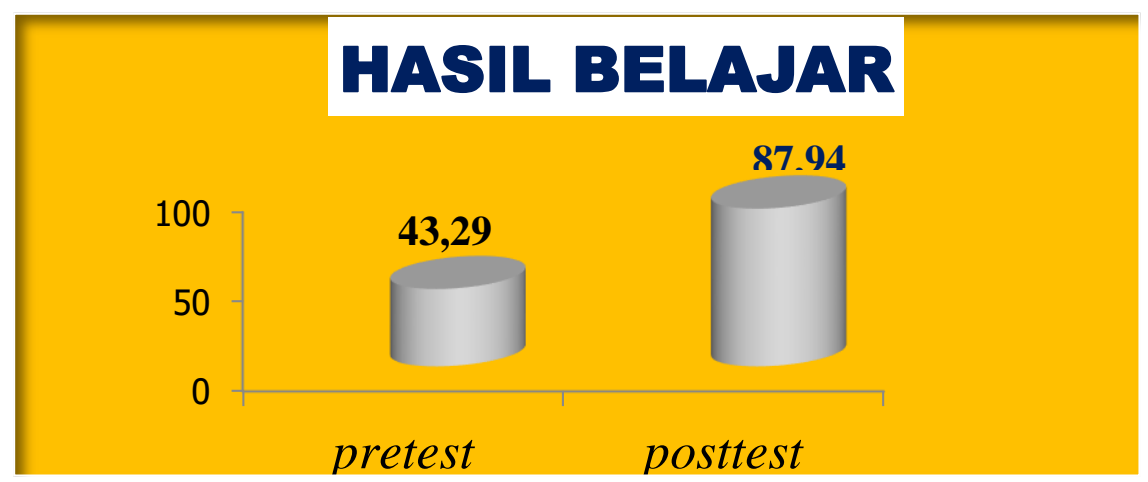

Hasil kesimpulan penelitian ini didukung dengan hasil penelitian yang dilakukan oleh Amrah (2020) menyimpulkan bahwa penggunaan media video pembelajaran memiliki dampak terhadap hasil belajar matematika siswa pada kelas IV SDN 24 Kalibone Kabupaten Pangkajene dan Kepulauan. Dapat diketahui dari hasil posttest lebih besar dibandingkan hasil pretest yakni ( 83,97 > 61,21).

Hasil penelitian ini didukung oleh hasil penelitian Lina Novita (2019) menyimpulkan bahwa penggunaan media video pembelajaran memiliki dampak terhadap hasil belajar siswa SD. Kesimpulan penelitian ini juga didukung dengan hasil penelitian yang dilakukan oleh Azis (2018) menyimpulkan bahwa penggunaan media video pembelajaran memiliki dampak terhadap hasil belajar siswa materi peredaran darah di sekolah dasar. Dapat diketahui dari hasil posttest lebih besar dibandingkan hasil pretest yakni ( 77,17 > 43,67).

\section{KESIMPULAN}

Berdasarkan penyajian hasil penelitian dan pembahasan disimpulkan bahwa: 1) Hasil belajar siswa pada mata pelajaran matematika siswa sebelum menggunakan media video pembelajaran di kelas IV SDN Kedungbanteng Sidoarjo tergolong pada kategori rendah. Hal ini terbukti dari nilai rata-rata 43,29. 2) Hasil belajar siswa pada mata pelajaran matematika siswa sesudah menggunakan media video pembelajaran di kelas IV SDN Kedungbanteng Sidoarjo tergolong pada kategori tinggi. Hal ini terbukti dari nilai rata-rata 87,94. 3) Ada pengaruh penggunaan media video pembelajaran terhadap hasil belajar pada mata pelajaran matematika di kelas IV SDN Kedungbanteng Sidoarjo. Hal ini didasarkan pada hasil uji paired sample t-test nilai signifikan sebesar 0,000 lebih kecil dari signifikan $0,05(0,000<0,05)$, sehingga hipotesis $\left(H_{1}\right)$ diterima.

\section{DAFTAR PUSTAKA}

Amalia, J. R. (2015). Penggunaan Media Pembelajaran Interaktif Untuk Meningkatkan Hasil Belajar Siswa Dalam Mata Pelajaran Hygiene Sanitasi Dan Keselamatan Kerja Pada Siswa Kelas X Di Smkn 1 Kudus Tahun Pelajaran 2014 / 2015. Universitas Negeri Semarang.

Amrah, Sahabuddin, E. S., \& Atirah, R. D. (2020). Pengaruh Penggunaan Media Video Pembelajaran Matematika Terhadap Minat Dan Hasil Belajar Siswa Kelas Iv Sdn 24 Kalibone Kabupaten Pangkajene Dan Kepulauan. Jurnal Madrasah Ibtidaiyah, 2(1), 47-66. Http://Eprints.Unm.Ac.Id/18650/

Arafah, Z. U. (2018). Pengembangan Media Pembelajaran Video Interaktif Berbasis Problem Solving Guna Meningkatkan Minat Dan Hasil Belajar Peserta Didik Pada Materi Gerak Parabola. Universitas Negeri Yogyakarta.

Arcat. (2020). Pengaruh Penggunaan Video Pembelajaran Terhadap Hasil Belajar Komputer 1 Mahasiswa 
3269 Pengaruh Penggunaan Media Video Pembelajaran terhadap Hasil Belajar pada Mata Pelajaran Matematika Siswa Sekolah Dasar - Yunita Prastica, Muhammad Thamrin Hidayat, Syamsul Ghufron, Akhwani

DOI: https://doi.org/10.31004/basicedu.v5i5.1327

Pendidikan Matematika Semester Ii. Jurnal Absis, 3(1), 250-256. Https://Doi.Org/Https://Doi.Org/10.30606/Absis.V3i1.496

Azis, R., Taiyeb, A. M., \& Muis, A. (2018). Pengaruh Penggunaan Video Pembelajaran Terhadap Motivasi Dan Hasil Belajar Siswa Pada Materi Sistem Peredaran Darah. Prosiding Seminar Nasional Biologi Dan Pembelajarannya, 461-466. Https://Ojs.Unm.Ac.Id/Semnasbio/Article/View/7184

Badriyah, U. (2017). Upaya Meningkatkan Hasil Belajar Matematika Siswa Pada Materi Himpunan Melalui Model Pembelajaran Kooperatif Tipe Numbered Head Together Di Kelas Vii-A Mts Aziddin Medan T.P 2016-2017 [Universitas Islam Negeri Sumatera Utara]. Http://Repository.Uinsu.Ac.Id/3151/

Daryanto. (2016). Media Pembelajaran (Perannya Sangat Penting Dalam Mencapai Tujuan Pembelajaran) (Edisi Ke-2). Gava Media.

Fauziyyah, Z. (2019). Pengembangan Media Video Pembelajaran Untuk Meningkatkan Keterampilan Menyimak Dan Berbicara Siswa Kelas Iii Sdn Merjosari 2 Malang [Universitas Islam Negeri Maulana Malik Ibrahim]. Http://Etheses.Uin-Malang.Ac.Id/16642/

Gunawan, D. (2020). Pengaruh Media Video Interaktif Terhadap Hasil Belajar Kognitif Kelasa Iv Sd Negeri 2 Karangrejo Trenggalek. Eduproxima: Jurnal Ilmiah Pendidikan Ipa, 2(1), 1-9. Https://Doi.Org/10.29100/Eduproxima.V2i1.1489

Indrawati. (2012). Penggunaan Media Audio Visual Sebagai Upaya Meningkatkan Aktivitas Dan Hasil Belajar Materi Mengidentifikasi Ragam Lagu Daerah Pada Siswa Kelas V Sd Negeri 04 Serang Petarukkan Pemalang [Universitas Negeri Semarang]. Http://Lib.Unnes.Ac.Id/19225/

Murningsih, E. S. (2014). Meningkatkan Hasil Belajar Siswa Melalui Media Pembelajaran Multimedia $\begin{array}{llll}\text { Interaktif. } \quad \text { Jurnal } & \text { 214-229. }\end{array}$ Https://Www.Journal.Stitpemalang.Ac.Id/Index.Php/Madaniyah/Article/View/42

Novita, L., Sukmanasa, E., \& Pratama, M. Y. (2019). Penggunaan Media Pembelajaran Video Terhadap Hasil Belajar Siswa Sd. Indonesian Journal Of Primary Education Penggunaan, 3(2), 64-72. Http://Ejournal.Upi.Edu/Index.Php/Ijpe/Index

Nurdiansah, A. (2017). Studi Kompetensi Guru Dalam Memanfaatkan Media Pembelajaran Berbasis Teknologi Informasi Dan Komunikasi (Tik) Di Smk Nu Ungaran [Universitas Negeri Semarang]. Http://Lib.Unnes.Ac.Id/29531/

Sarosa, D., \& Khairudin, M. (2016). Pengembangan Media Pembelajaran Interaktif Pada Mata Pelajaran Mikroprosesor Di Smk Negeri 2 Pati. E-Journal Universitas Negeri Yogyakarta, 6(1), 25-32.

Sawitri, E. (2019). Pemanfaatan Media Gambar Untuk Meningkatkan Hasil Belajar Siswa Kelas Iv Madrasah Ibtidaiyah Al-Munawwarah Kota Jambi [Uin Sulthan Thaha Saifuddin Jambi]. Http://Repository.Uinjambi.Ac.Id/Id/Eprint/1846

Suciyati, \& Mariamah. (2018). Hubungan Antara Minat Belajar Dengan Hasil Belajar Matematika Pada Siswa Kelas V Sd Negeri 04 Sila. Jurnal Pendidikan Mipa, 8(2), 142-149. Https://Doi.Org/10.37630/Jpm.V8i2.265

Sudjana, N. (2009). Penilaian Hasil Proses Belajar Mengajar. Pt. Remaja Rosda Karya.

Trijono, R. (2015). Metodologi Penelitian Kuantitatif. Papas Sinar Sinanti.

Usman, B. (2002). Media Pembelajaran. Ciputat Pers.

Zunidar. (2019). Peran Guru Dalam Inovasi Pembelajaran. Nizhamiyah, Ix(2), 41-56. Https://Doi.Org/Http://Dx.Doi.Org/10.30821/Niz.V9i2.550 